\title{
Challenges for School Libraries in the digital age: A study on the knowledge seeking pattern among male and female students in Sri Lanka
}

\author{
Yasindri Vishnika Premadasa \\ Holy Family Convent, Bambalapitiya, Colombo-4 \\ Sri Lanka \\ vishnika@gmail.com
}

\begin{abstract}
Current literature shows that very limited research has been done with respect to young school children and their usage of print and electronic media, which implies its timely importance of such research for the policy makers, educators, libraries, education reformists and the young school children of Sri Lanka. This paper discuss a comparative study that was carried out to investigate the knowledge seeking patterns among students are changing from print to electronic media. The survey was conducted among four schools in Sri Lanka, comprised of a total of 400 students ranging from 14 years (grade nine students) to 18 years (grade thirteen students). Our study showed, $66 \%$ of grade nine students, $77 \%$ of grade ten students, $72 \%$ of grade eleven students and $80 \%$ of the grade twelve students prefer electronic media over print media. Our study also showed a gender effect on the use of electronic media.
\end{abstract}

Keywords: electronic media, print media, students, gender 


\section{Introduction}

The $21^{\text {st }}$ century was declared as a digital era. As of June 2010, 1.7 million internet users were recorded in Sri Lanka, which accounts to $8.3 \%$ of the Sri Lankan total population (Internet World Stats, 2012). When considering more facts and figures related to digital usage of Sri Lanka, it shows that very limited research has been done with respect to young school children and their usage of print and electronic media. This implies its timely importance of such research for the school librarians, policy makers, educators, education reformists as well as the young school children of Sri Lanka.

In general, children and young community are fast adopters of the internet for communication, entertainment and education (Chan and Fang 2007). They are considered as Y generation. Generation Y grew up with technology and rely on the technology to perform their jobs better. Armed with, laptops, cellular phones and other electronic devices, Generation Y prefers to communicate through e-mail and text messaging rather than face-to-face contact and prefers webinars and online technology to traditional lecture-based presentations. (Gunn and Donahue 2008). Internet use as an information seeking tool is becoming common among students (Ucak 2007). Many studies have been reported on the internet use by individuals and a very comprehensive study has been reported by the OCLC (The Online Computer Library Center, Inc.) Market report in 2005. In this study 3300 individuals from Australia, Britain, Canada, Singapore and United States have been questioned on their usage of internet, electronic media and library usage where the study found out individuals preferred internet over library resources. Children differ from adult learners in many ways, but there are also commonalities across learners of all ages (Bransford et al. 2004). In 2001, computer and internet use was more widespread among school-age children and adolescents in the United States than among adults. However, the dramatic increase in the use of the Internet in recent years has led to pathological use which can also be termed as Internet addiction (Nalwa and Anand 2003). Increasing spreading of the internet among adolescents was reported in many studies (Gross 2004; Tenopir 2003; Kayany and Yelsma 2000).

Previous research on media usage of children and adolescents found that the amount of time spent on various media correlated to social and demographic variables (Comstock and Scharrer 1999: Comstock 1991). Socioeconomics plays a huge role in the use of electronics among school children. In a comprehensive study carried out by DeBell and Chapman in 2003 for a group of children ranging from kindergarten through grade 12, reported that the use of internet is divided along demographic and socioeconomic factors. They reported that the use of computers and internet is higher among Whites than among Blacks and Hispanic students. They also reported that students living with well-educated parents are more likely to use these technologies than those living with less educated parents. Same pattern was seen with respect to family income. Children living in households with higher family incomes are more likely to use computers and the Internet than those living in lower income households (DeBell and Chapman 2006)

With regard to the Sri Lankan education system, Information Technology (IT) has been a significant component since 1983 (Hanna 2007). However lack of infrastructure facilities due to economic constraints has been a challenge. According to a study carried out in 1995, out of 9790 Government Schools only $41 \%$ had permanent libraries whereas out of 85 Private Schools $80 \%$ had permanent libraries and with respect to 87 International Schools, $100 \%$ of the international schools had permanent libraries (Wijetunga \& Alahakoon, 2005). The Sri 
Lankan Government National Policy of School Education affirms the commitment of the government towards providing the state of the art knowledge in IT to Sri Lanka's younger generation, preparing them to face the challengers in the $21^{\text {st }}$ century. The increasing amount of time that children are spending on computers lead to a question of how the use of computers impact their life styles (Gross et al. 2004). Several research projects on children and young adult's internet usage are now underway showing its prime importance as a major research agenda (Livingstone, 2003).

With regard to the relationship between the internet and older forms of media (print media such as newspapers, books, magazines, journal articles etc.), many studies revealed that there is a decreased use of older media with the introduction of the internet (Dimmick et al. 2004; Kayany and Yelsma 2000; Nie and Hillygus 2002). In contrast Ziming Liu (2006) reported that graduate students desire to meet their information needs through a mix of print and online resources. Adolescents are the most active users of new communication technologies. In the year 2009, 93\% of adolescents aged 12-17 in the United States were online (Jones and Fox 2009). In another study in East Asia, the internet usage by adolescents in Korea, Taiwan and Singapore had already reached $90 \%$ by the year 2001 (Jung et al. 2005). Despite the increasing attention given to adolescents' internet usage, not many studies have examined their types of internet use in the context of other media (Jung et al. 2012). As information seeking tools, students use variety of web resources for assignments, including search engines, web portals, coursespecific web sites, and university library web sites as well (Tenopir, 2003).

Most educational policy makers, practitioners, and parents assume that use of computers and internet will influence class room teaching for teachers and learning skills of students (Cuban 2001). A research study that was carried out in 56,000 households in the United States showed that only $35 \%$ of the students used computers and internet and they represented poor income families where their parents had no high school degrees. In contrast, $88 \%$ of the students used computers and internet for learning, who had at least one parent who had attended university education came from families having at least one parent with university education (DeBell and Chapman, 2006). Furthermore it was reported that use of internet and computers by students of low income families showed improvement in their academic performance.

Many have reported that the reading patterns among younger generation is changing and with an increasing amount of time spent reading electronic documents, a screen-based reading behavior is emerging (Liu 2005; Troll 2002, MacWhinnie 2003). Increasing use of technology for accessing information has brought changes in the student's usage of academic libraries and library resources (MacWhinnie 2003). As a result academic libraries are changing in response to changes in the learning and research environment and changes in the behavior of library users (Troll 2002). However it has become very difficult for the library administrators to respond to the transforming needs and expectations of the digital age library users (Troll 2002). Currently there is no standard, comparable data to assess digital library trends across academic libraries. Modern day libraries of all sizes and types are embracing digital collections, although most libraries will continue to offer both print and digital collections for many years to come (Tenopir, 2003) 


\section{Methodology}

This study was based on a survey method. School population was represented by four government National Schools. A sample population of randomly selected 400 Students from Grade 9-13 (Table 3) was tested for their usage of print and electronic media as an information seeking tool in the digital age. I got the prior approval from the school authorities and the consent from the school children, before delivering the questionnaire for the survey. The students and the administrators were well informed about the study and how the collected data will be used. Class teachers distributed the questionnaires to students and then collected them afterwards in the presence of myself. A quantitative analysis was performed from the data obtained.

The first part of the questionnaire was considered to evaluate the current usage of print and electronic media as a study tool among school children. The first part of the questionnaire further gathered what type of websites/ web sources and what type of print media (Journals, news papers, bulletins etc.) used by the sample population and also compared between female and male students. The second part of the questionnaire targeted to get information on the amount of time spent, how frequent they use the internet and for what purposes do they use internet other than academic requirement. The third part of the questionnaire was designed to find any relationship with the social structure and family income.

\section{Results}

\section{General trend of the use of print media and electronic media:}

The results from the study showed that students depend on both print and electronic media as an information seeking tool (Figure 1). Furthermore the data shows that there is a huge impact by the introduction of electronic media. On a percentage basis $66 \%$ of grade nine students, $77 \%$ of grade ten students, $72 \%$ of grade eleven students and $80 \%$ of the grade twelve students prefer electronic media over print media.

The results from this study clearly shows that among all the students regardless of the grade, the use of electronic media is significantly popular than the use of print media. This study data also shows that students use electronic media more as an information seeking tool for educational purposes (Figure 2).

However print media still has a substantial role with respect to information seeking among students. The survey also showed similar patterns in the use of print media among the two genders (Figure 4 and Figure 5).With respect to print media, both male and female students preferred text books and reference books for information seeking. Print media was still popular among students as an information seeking tool, however it was less popular than electronic media. There are no previous studies been conducted in Sri Lanka to compare these results. 

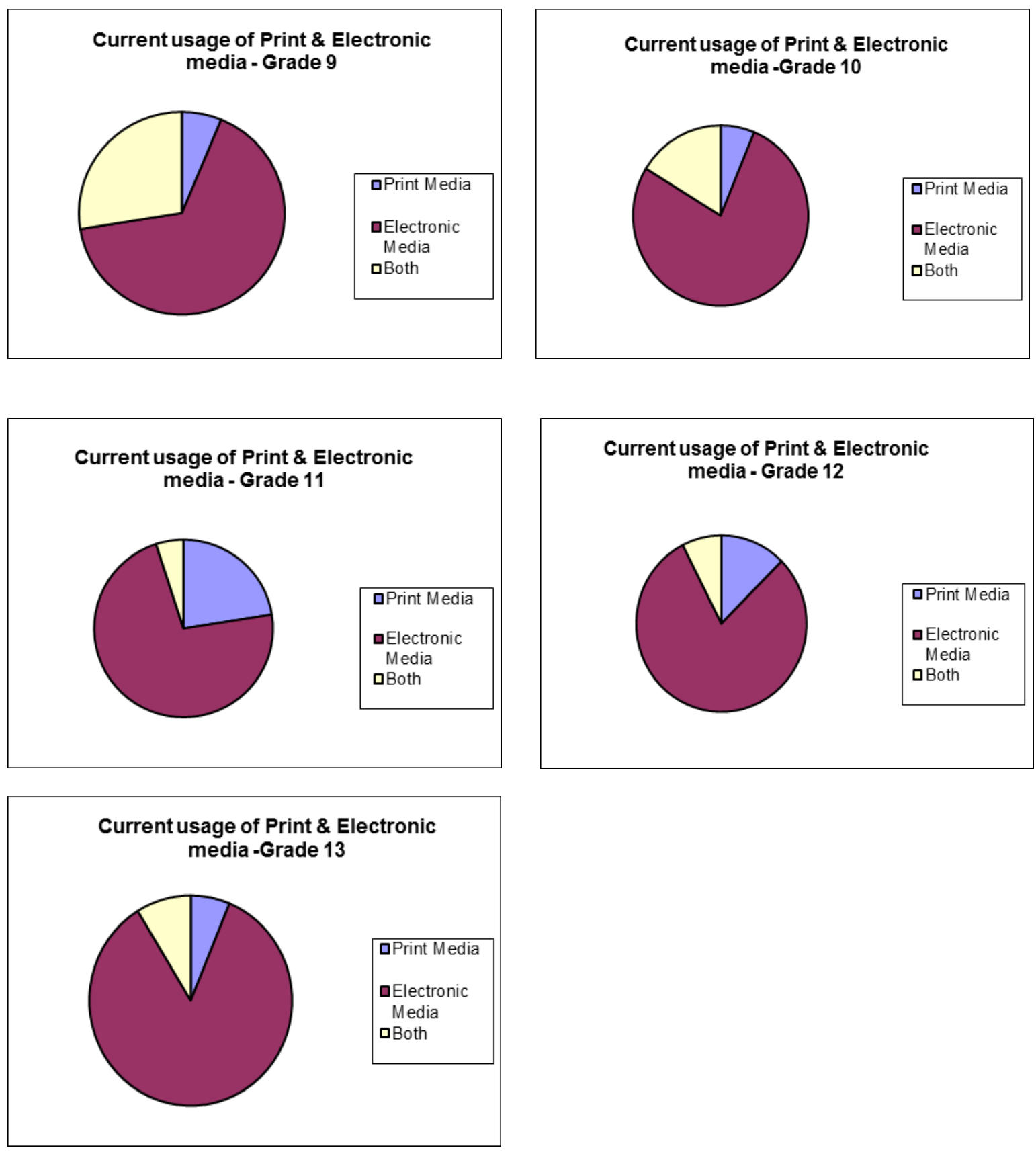

Figure 1: Usage of Print and Electronic media by grade nine, grade ten, grade eleven, grade twelve and grade thirteen students 
There are many studies from other countries where they reported similar findings to the results, I have reported in this paper. Results from the studies conducted in United States, by Kaiser Family Foundation (2010) reveal that college students and students ranging from 8 to 18 years old are heavily relying on the web for both general and academic information, and that they expect this trend to increase over time. This might be mainly due to the easy accessibility of the electronic media among student populations in the western countries. Even with limited accessibility and low infrastructure students in our research showed a similar trend and this would suggest that more students will rely on the use of electronic media in the future.

\section{Gender wise electronic media usage:}

This survey showed that in general male students use internet more than the female students (Figure 2 and Figure 3). This was seen in all categories from education to news, sports, entertainment, and social network. So there is a significant relationship with reference to gender and the use of internet. Similar results were reported by D.G. Singer and J. L. Singer (2001). They reported that teenage boys spent more time in electronic media than the teen girls, even though both of them had the same facilities to access electronic media. So our results and findings from other published studies show that there is a significant relationship between the genders in the use of electronic media (Figure 2 and Figure 3).

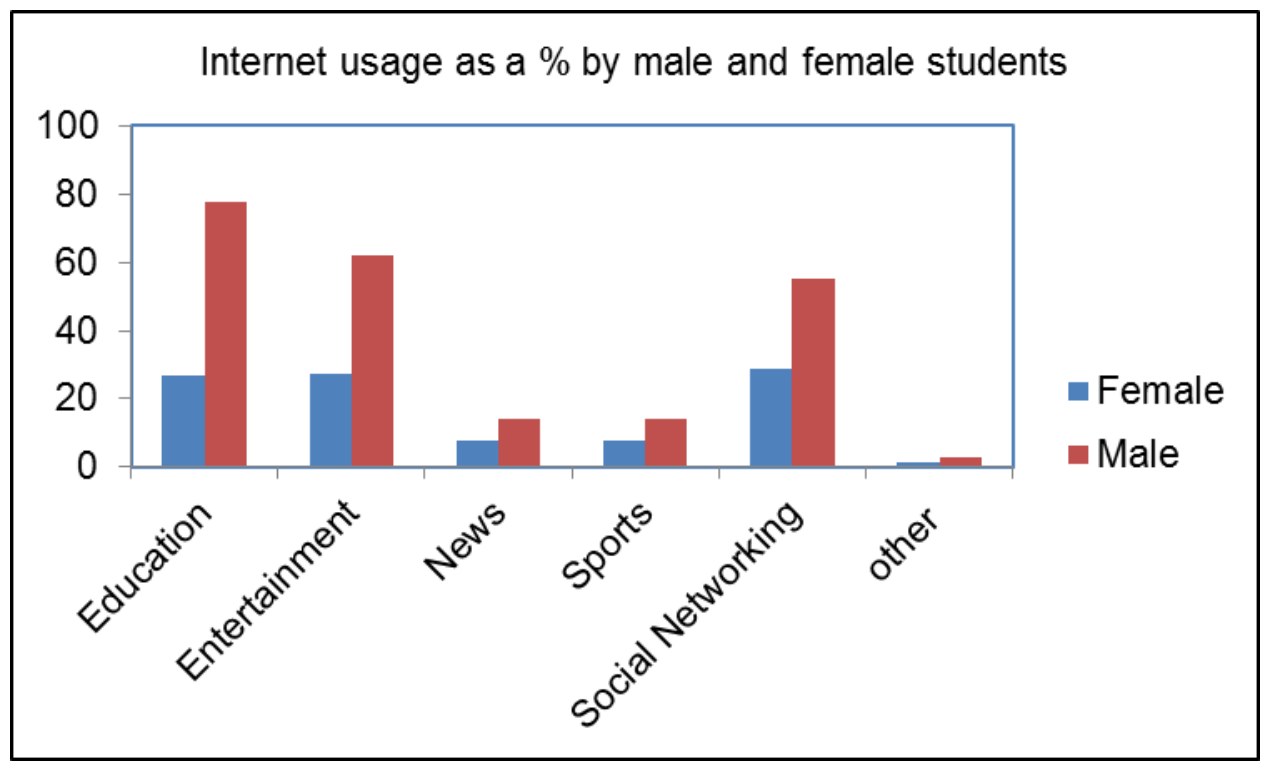

Figure 2: Usage of internet by male and female students (Note: Male = total male students from grade 9 through grade 13 and Female = total female students from grade 9 through grade 13) 


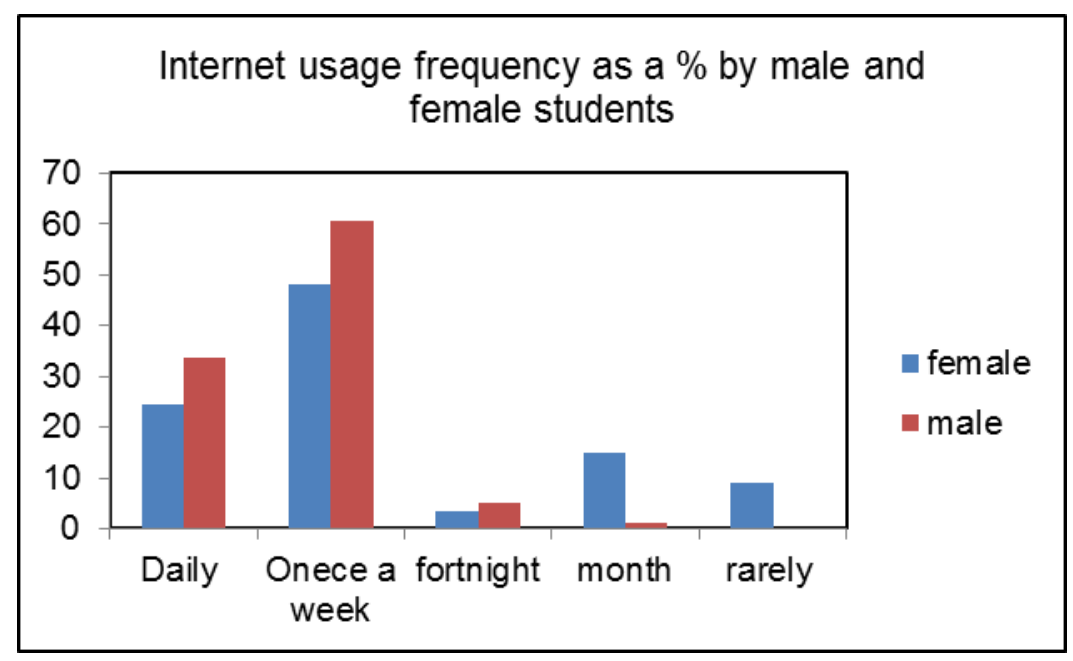

Figure 3: Internet usage frequency by male and female students (Note: Male = total male students from grade 9 through grade 13 and Female $=$ total female students from grade 9 through grade 13)

Some studies (Beentjes et al. 2001) showed that males were found to spend more time on computers for playing electronic games than for educational purposes than females (Beentjes et al. 2001). However my study showed that the male students spent more time on electronic media regardless whether its education or entertainment (Figure $2 \& 3$ ).

Print media usage among male students as a $\%$

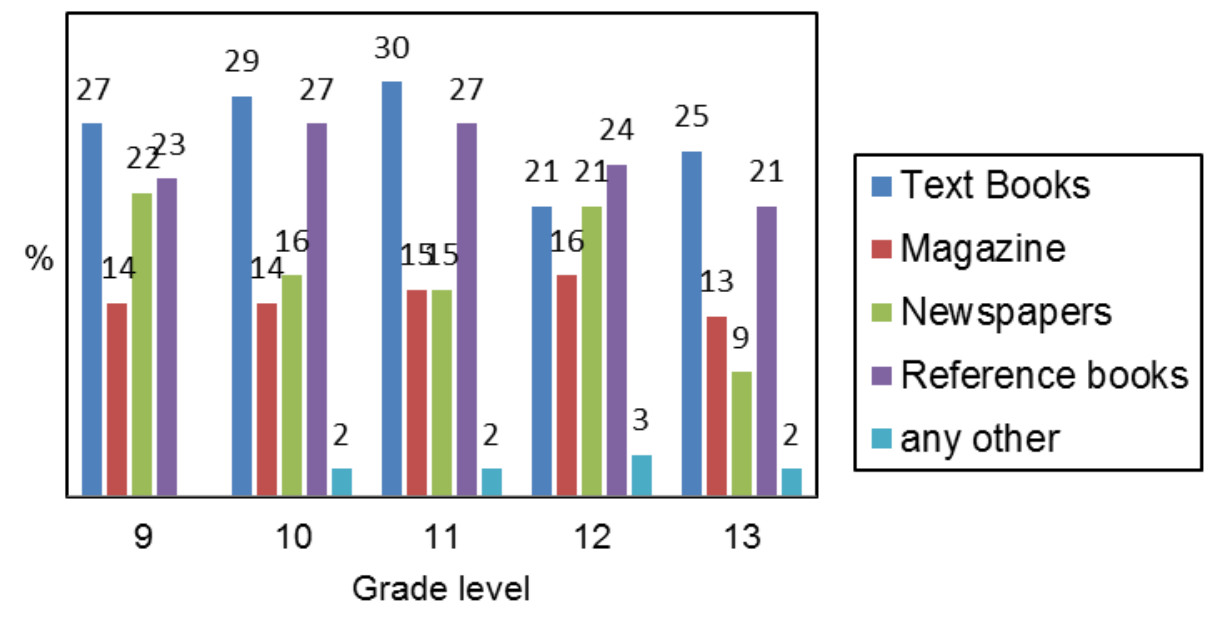

Figure 4: Print media usage among male students as a percenatge 


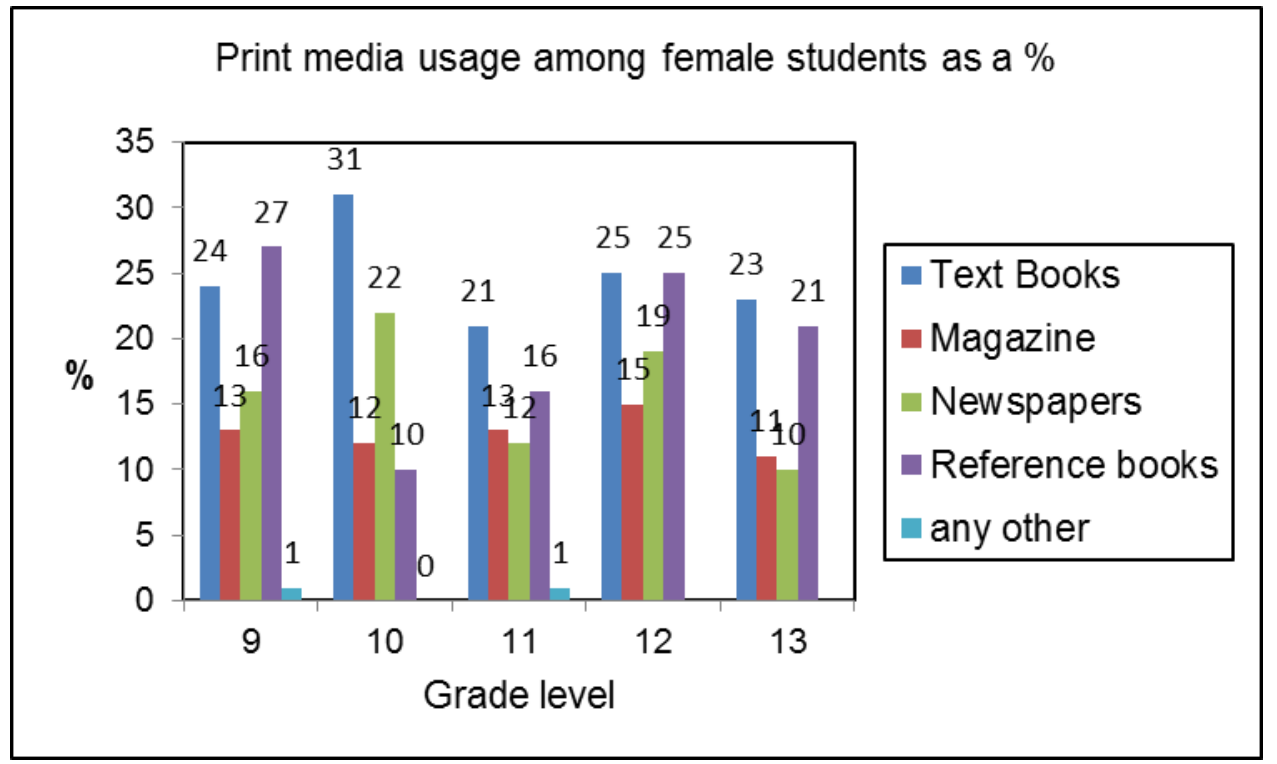

Figure 5: Print media usage among female students as a percenatge

\section{Gender wise internet usage frequency:}

In my study I was able to analyze the internet usage frequency too. The main goal was to see whether there is any gender wise difference in how often they use internet (Figure 3).

Data collected in this study showed that the frequency of internet usage increased in male students as they aged. Daily internet usage among male students was $25 \%, 48 \%, 50 \%, 58 \%$ and $65 \%$ as they went from grade $9,10,11,12$ to 13 respectively. Except for nine graders, in all other male student grades, majority of the male students used internet daily. Similarly the frequency of internet usage among female students too increased from $13 \%$ to $18 \%$ to $43 \%$ from grade 9, 10, 11 and grade12. This could be explained as students aged they needed more information for their school assignments and as a result depended more on internet as an information seeking tool. Other than that, as students aged, their social connections with their peers increased and so did the internet use for linking with friends on social media such as face book. 


\section{Gender wise Print media usage}

According to the data, with reference to print media (figure 4 and Figure 5) male students were found to be reading more text books and reference books than the female students. However the rest of the printing media does not show much of a difference. In contradicting to this study, Livingstone and Moira. (2001) reported that girls spent more time on reading.

\section{Impact of parent control on electronic media usage by students}

Parent restrictions seem to be the number one significant factor to restrict students using electronic media. Parents expressed that they think students pay too much time playing video games than using for educational purposes. This was observed for both genders. Similar results were reported in Kaiser family foundation study (2010) where there was nearly 3 hours of less daily internet usage by the students who had parent control than the students who did not have any restrictions at home.

\section{Impact of household income on the use of electronic media among students}

Household income is one of the major factors that determined the use of electronic media by students. From this study, $36 \%$ of the male students mentioned their main household income as private business owned by their parents whereas only $20 \%$ of the female students said their parents own private business. In general people who own businesses have higher income levels than the people who worked for the private or government sector who will settle on a fixed monthly income. This could be another factor that the data showed more male students using electronic media than female students. In addition to the household income cultural restrictions may have also impacted female students to spend less time on electronic media than the male students.. Unfortunately the typical male dominating Asian culture has a big influence and control on female students. Usually male students have more freedom from their parents and they tend to visit places where they can access internet such as visiting libraries, spending after school hours, visiting internet cafes or visiting friends who have more access to electronic media. According to the Sri Lankan culture, female students do not have much freedom from their parents and as a result they tend to spend more time at home and have less access for electronic media unless internet is available at home 


\section{Social networking and its impact of electronic media among students}

Use of internet for social networking is enormously popular among the teenagers. In all grades irrespective of the gender face book was found to be the most popularly used networking website among Sri Lankan students (Figure 6 and Figure 7). Among male students 35\% of grade nine students used face book as their social network media and it rose to $90 \%$ among grade thirteen male students. Similar results were observed in female students where face book was used by $25 \%$ of the grade nine students and it rose to $75 \%$ among grade thirteen students. Obviously the least used social networking website among students was the Linked and it was ranging from zero to $2 \%$. This is very explainable as students of this age category are not employed or professionally qualified..

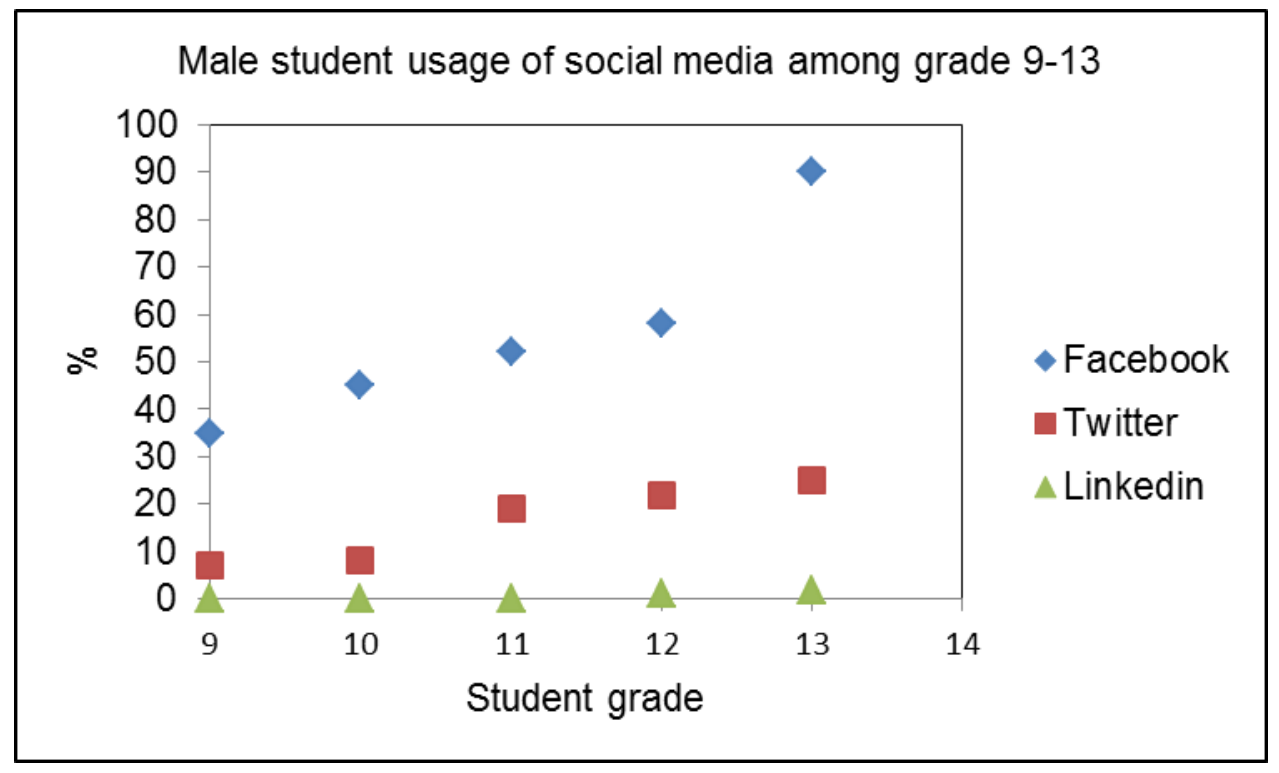

Figure 6: Use of social media among male students 


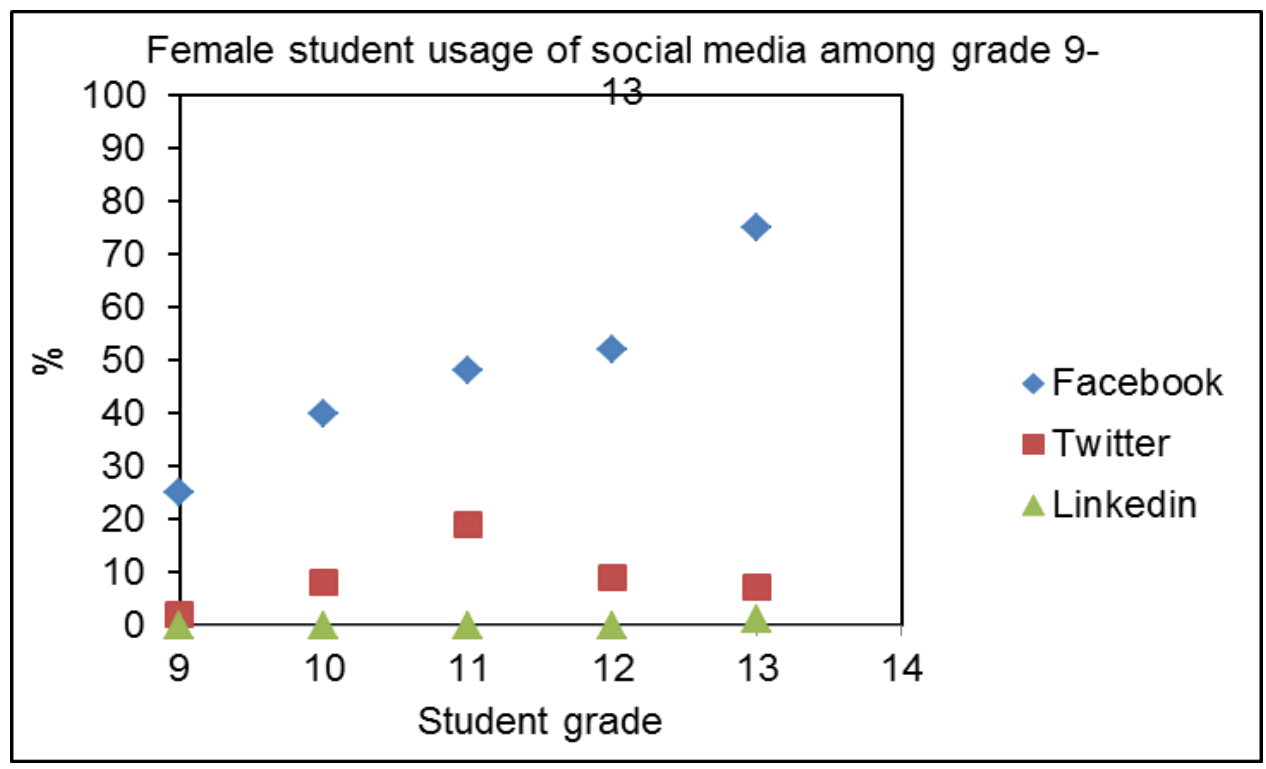

Figure 7: Use of social media among female students

\section{Most common reasons of internet usage by male and female students}

Education is the most common reason (ranging from $70 \%$ to $90 \%$ ) for the internet use among both male and female students (Figure 2). Hence it is very clear that despite the use of internet for connecting with friends or entertainment, great amount of information is searched via internet for educational purposes. Entertainment is the next most common usage by school children (Figure 2). When considered male students, $28 \%$ of the $9^{\text {th }}$ graders used internet for social networking and that number doubled reaching to $63 \%$ for grade 13 male students. A similar trend was seen among female students where $40 \%$ of nine graders used internet for social networking and it almost doubled in 13 graders reaching to 78\% .Our results clearly show that, as children grow older they make more friends and then use social networks like Facebook and twitter to stay connected. News and sports are the least searched areas using internet and this behavior was observed in both male as well as female students.

\section{Most common place where internet is accessed by male and female students}

Based on my study, Home seems to be the most common place for both male and female students to access the internet. Use of internet at home ranges from 90 to $100 \%$ in male students and 75 to $88 \%$ among female students. Use of school computer facilities for internet use in male students range from 8 to $20 \%$ and the figures are very closely matching with female students where the range is from 12 to $20 \%$. The data suggest that Sri Lankan schools do not have sufficient computer facilities for student's access to meet their their educational purposes. School is the second mostly used location for internet access by both male and female students. 


\section{Findings and conclusions}

This study revealed that there is a great trend among school children towards the use of electronic media over print media. This was evident in both male and female students though male students' usage of electronic media was much more than the usage by female students. The survey showed Education as the most common reason for the internet use among both male and female students. Even though social networking such as face book was very popular among both male and female students, internet as an information seeking tool was the top most demanding factor.

Based on my study more than the school structure, the social structure and the family income were the number one determinant factors in deciding the usage of electronic media among students. With reference to the social structure, our study showed that parental control to be the most dominant factor in deciding the usage of electronic media among students. This was mainly affected for the use of electronic media by female students, At each school at each grade female students had great amount of parental restrictions compared to their male counterparts. However even the male students had a considerable amount of parental restrictions for accessing electronic media. The household income levels had the greatest impact. Students who had main family income from family owned businesses showed more usage of electronic media than by other students. It is assumed that business families have much higher income than the families who get a fixed income by working for the private or government sector and thereby these parents had more money to spend on buying electronic devices for their children.

Based on this study electronic media seems to be the most popular information seeking tool among school children of the digital age.

\section{Research Limitations}

This study was only restricted to the greater Colombo area and further it had to be limited to four schools. Due to the time factor and the economic factor this study was not able to analyze in a larger student population. The student population in this study was not large enough to generalize the findings to the whole greater Colombo area. Furthermore, this study was done in four National schools. National schools have much more facilities than most of the other schools found in the Colombo suburbs. Therefore these findings cannot be generalized to the Colombo student population. However this study will be a guide for the future studies as it gives a glimpse of the situation among school children and their usage of electronic media and print media in the digital age.

\section{Suggestions for further research}

This study should be repeated with a greater student population representing both National schools as well as non- National Schools. 


\section{Reference List}

Beentjes, J. W. J., Koolstra, C. M., Marseille, N., \& Van-der- Voot, T. H. A. (2001) Children use of different media for how long and why?, Children and Their Changing Media Environment: A European Comparative Study. Lawrence Erlbaum Associates Inc. New Jersey

Bransford, J. D., Brown, A. L., Cocking, R. R., Donovon, M. S. , Pellegrino (2004). How people learn: Brain, Mind, Experience, and School. (Expanded Edition). National Academy Press, Washington DC.

Chan, K., \& Fang, W. (2007). Use of Internet and traditional media among young people, Young Consumers, 8(4), 244-256.

Comstock, G. (1991). Television and the American Child, Academic Press, San Diego, CA.

Comstock, G., \& Scharrer, E. (1999). Television: What's on, Who's Watching, and What It Means, Academic Press, San Diego, CA.

Cuban, L. (2001). Oversold and Underused: Reforming Schools Through Technology, 19802000.Cambridge MA: Harvard University Press

DeBell, M., \& Chapman C. (2003). Computer and Internet use by children and adolescents in 2001:

Statistical analysis report. Washington, DC: U.S. Department of Education.

http://nces.ed.gov/pubs2004/2004014.pdf

DeBell, M., \& Chapman, C. (2006). Computer and Internet use by students in 2003. National Center for Educational Statistics. U.S. Department of Education, Washington, DC. Retrieved August 1, 2007, from http://nces.ed.gov/pubs2006/2006065.pdf

Dimmick, J., Chen, Y. \& Li, Z. (2004). Competition between the internet and traditional news media: The gratification opportunities niche dimension. The Journal of Media Economics 17(1), 19-33

Hanna, N. K. (2007). From envisioning to Designing e-Development. The experience of Sri Lanka. The International Bank for Reconstruction and Development. The World Bank, Washington D.C.

Gross, E.F. (2004), Adolescent Internet use: What we expect, what teens report. Applied Developmental Psychology, 25, 633-649.

Gunn, J. B., \& Donahue, E. H. (2008). Children and Electronic Media, Vol. 18 (1), 3-10

Internet World Stats (2012), Internet usage and world population statistics, from www.internetworldstats.com/stats.htm 
Jones, S., \& Fox, S. (2009). Generations online in 2009. from http:// www.pewinternet.org

Jung, J. Y., Kim, Y., \& Lin, W. Y. (2005). The influence of social environment on internet connectedness of adolescents in Seoul, Singapore and Taipei. New Media and Society. 14(6), 969-986

Jung, J. Y., Lin, W. Y., \& Kim, Y. C. (2012). The dynamic relationship between East Asia adolescents' use of the internet and their use of other media. New Media and Society. 7(1), 6488

Kaiser Family Foundation. (2010). Generation M2: Media in the lives of 8- to 18-Year Olds. Retrieved from http://www.kff.org/entmedia/mh012010pkg.cfm

Kayany, J. M., \& Yelsma, P. (2000). Displacement effects of online media in the socio-technical context of households. Journal of Broadcasting and Electronic Media 44(2), 215-229

Liu. Z (2005). Reading behavior in the digital environment: Changes in reading behavior over the past ten years. Journal of Documentation. 61(6)

Livingstone, S. (2003). Childrens use of the internet: reflections on the emerging research agenda. New Media and Society, 5(2), 147-166.

Livingstone, S., Moira, B. (2001). Children and their changing media environment: A European comparative study. Lawrence Erlbaum Associates Inc. New Jersey

MacWhinnie, L. A. (2003). The Academic Library Of The Future Libraries and the Academy, 3(2) from http://muse.jhu.edu/journals/portal libraries and the academy/

Nalwa, K. \& Anand, A.P. (2003). Internet addiction in students a cause of concern, Cyber Psychology \& Behavior, 6(6), 653-656.

Nie, N. H., \& Hillygus, D. S. (2002). The impact of internet use on sociability Time-diary findings. IT and Society 1(1), 1-20

OCLC Market Report (2005), Perceptions of libraries and information resources, www.oclc.org/ reports/2005perceptions.htm

Singer, D. G. \& Singer, J. L. (2001). Hand Book of Children and the Media. Sage Publications Inc.London

Tenopir, C. (2003). Use and Users of Electronic Library Resources: An overview and analysis of recent research studies. Council on Library and Information Resources. from http://works.bepress.com/carol tenopir/92

Troll, D. A. (2002). How and Why Libraries are changing. What we know and what we need to know. Libraries and the Academy, 2(1)

Ucak, N. O. (2007). Internet use Habits of Students of the Department of Information Management, The Journal of Academic Librarianship, 33 (6). 
Wijetunga, P. \& Alahakoon, U. P. (2005). The Information Literacy Model Developed in Si Lanka to underpin changing education programs of Sri Lanka. Sri Lanka Journal of Librarianship and Information Management, 1(1) 31-41

Ziming, L. (2006). Print vs Electronic Resources: A study of user perceptions, preferences and use. Information Processing and Management. 42(2), 583-592

\section{Biography}

Yasindri Vishnika Premadasa received her B. A. degree in 2002 and M.A. degree in Library and Information Science in 2015 from University of Kelaniya, Sri Lanka. She is working as a Librarian at Holy Family Convent Bambalapitiya, Colombo, Sri Lanka since 2005. Her research interests are studying student behavioral patterns in information seeking and also studying relationship of gender and information seeking patterns. 